\title{
Using Game Approach in Improving Learning Outcomes of Pencak Silat
}

\author{
Widiastuti $^{1}$ \\ ${ }^{1}$ Universitas Negeri Jakarta (UNJ), Indonesia \\ Correspondence: Widiastuti, Universitas Negeri Jakarta (UNJ), Indonesia. E-mail: widiastuti@unj.ac.id \\ Received: February 12, 2014 Accepted: February 20, 2014 Online Published: February 28, 2014 \\ doi:10.5539/ass.v10n5p168 \\ URL: http://dx.doi.org/10.5539/ass.v10n5p168
}

\begin{abstract}
Pencak Silat lesson requires appropriate motor learning model to improve students skill. Game approach, as one of motor learning model, is intended to improve students' learning outcomes in Pencak Silat class. The objectives of this research are to improve Pencak Silat lecture, to improve students' performance, to enhance students' understanding of pencak silat lecture, and to apply game approach on the learning of Pencak Silat basic skills. This research uses action research method, which consists of several stages such as: planing, execution, observation, report and evaluation, and re-planning. Re-planning stage is the planning stage for the next cycle. On the first and second cycle, student have not been able to gain results as expected. On the third cycle, students' performance improvement has already achieved maximum target. Researcher found that game approach is able to improve students' learning outcome of Pencak Silat, increase students' creativity in terms of motor learning, and create supportive learning environment. Students, individually or in group, are able to explore and create motor learning model with game approach.
\end{abstract}

Keywords: pencak silat, game approach, learning outcome

\section{Introduction}

One of Pencak Silat course goals is to improve students' skills in Pencak silat martial art, so Pencak Silat course requires students to master several basic skills in Pencak Silat martial art. Therefore, Pencak Silat course model is needed to sharpen students' skills. One of the approaches used in Pencak Silat class in Universitas Negeri Jakarta is game approach. Game approach learning model is very suitable with Pencak Silat course objective to improve the performance and quality of students' skills in learning pencak silat. Conventional learning model in Pencak Silat lecture bores students and become a distraction factor in learning process. This fact suggests urgency to change learning model in Pencak Silat class. A new learning model is expected to boost students' skill better than the conventional way.

The new learning model is constructed based on the intention to make Pencak Silat class to be more involving, exciting, fun and motivating for students. The researcher used game approach as a substitute for conventional learning model to create larger involvement of students in class, bigger excitement to sharpen and learn new advanced skills, and motivating students to display the performance in class.

Changing the learning model requires syllabus changes. As a consequence, lecturer needs to re-asses the form of syllabus that optimizes game approach learning model. Trial and error or experiments are needed to evaluate game approach role in optimizing students' learning process in the Pencak Silat class.

Game approach is a learning model, which demands more involvement from students or participants. On the other side, game approach can create fun learning process. Rusli Lutan (2001) said that a successful learning process is a learning that boosts learning process. Learning through movement experience to achieve specific objective is a natural form of physical education. The learning process in physical education takes place in physical activity, play, and sport activity. Teacher and student interaction are the medium to accomplish learning goals (Lutan, 2001, p. 18). Play is an activity, which contains fun and is conducted by free will without any external pressure (Wardani, 2009, p. 17-18).

Fun condition in learning process is also needed to provoke positive feeling and ambience, which is able to make learning process more acceptable. Therefore, physical education should have fun activities, which give joy to students when conducting the activity and give students room to grow individual creativity (Ibrahim, 2001, p. 42). 
Soemitro said that play is a natural instinct of human. As a natural desire, play is a basic need for every student. Therefore, in learning process play cannot be eliminated in a serious intention of knowledge transfer. Play is a form of self-actualization (Soemitro, 1991, p. 7). Docket and Flee added that play is student's need because through play student gradually obtains new knowledge. Play is a very unique activity because it is different from other activity like working which have specific goals. Play activity does not need any specific goals (Docket \& Fleer, 2000, p. 41-43).

Game approach in learning process is mainly based on Gross theory, which defines play is a useful learning mode to achieve specific learning goals. Gross theory explains that human tend to adjust the game they play based on growth level, physical development, social development, and mental development (Soemitro, 1991, p. 9).

Educational games can deliver knowledge to students through learning while playing. It can improve thinking development, individual creativity, and verbal communication which are strongly related to mental development and attitude. Educational games should provide inviting play environment, give secure and fun feeling to students, in order to achieve high quality learning process to student through fun activity.

In Pencak Silat class, game approach learning model is more effective than the conventional one. Game approach gives opportunity to students to interact freely without any injury risk because there is no impact when sequence of Pencak Silat stance is performed. Game approach will help student to learn new skill and movement faster and better.

Pencak is attack and defense in rhythmic movement, which creates martial art stance with prescribed rules of game. Silat is the essence of Pencak, which is used in fighting and self-defense. Pencak Silat match has several characteristics such as, stance pose, step pattern, coordination in attack-defense,and successive attack. Those characteristics are made to dictate athlete in Pencak Silat match. In Pencak Silat match, athlete should perform the stance pose, then Step pattern, and followed by attack or defense stance.

Pose stance in Pencak Silat is a preface of attacking strategy. As a preface, pose stance should provide good step pattern as a beginning of stance. According to Tinowati Tamat, step in Pencak Silat is movement of bodyweight supported on ball of foot from one to another in order to form new and firm body position (Tamat, 1986, p. 40).

The objectives of this research are to improve and increase the success in the implementation of Pencak Silat class, to increase students performance in Pencak Silat class, and, to motivate students to understand and apply game approach in learning basic techniques of Pencak Silat.

\section{Methodology}

This research uses the action research method consisting of the following phases; action planning, preparation and execution, observation, reflection and records the results of observations, and, replanning which is the determination of the learning models before continuing to step 2 for the next cycle.

Data obtained from the observation includes the following: 1) provide a test to student, 2) provide records obtained during the observation of the events in the next series of events at the time of the study, 3) self-reflection and changes that occur in the classroom through interviews, observations, and questionnaires, 4) linkages between planning and implementation of the plan from teaching plan and observation.

Students who take this course consists of 50 students; in which, 2 students have a very good basic technical ability, 8 students have good ability, and the rest do not have good basic skills of Pencak Silat. No student has ever repeated or taken this course in the previous semester.

Several steps are necessary to achieve the purpose of this research. The first is the need to define the designated plan, and made a lesson plan to determine and assess the problems in the learning process. The second stage is to analyze all the actions that will be used as a follow-up study toward learning model, which previously has been defined. The third is to conduct an analysis through observation and observation of actions according to a predetermined plan. Researchers conducted an analysis of the success of the materials that are tailored to the model that has been applied previously, to see the progress made by the learners. The fourth is to make a synthesis based on a comparative analysis of the results of observations with the theories related to produce reflections and actions that have been done in the field, so as to overcome the problems that arise when learning takes place earlier. The fifth is to create a framework that describes the conceptual impact of the actions from undertaken reflection.

For each cycle, researchers conducted the analysis and assessment in order to provide an analysis and improvements, which then followed by the reflection to analyze whether the learning achievement can be run as planned. This applies to subsequent cycles, and in the end the students can benefit from the methods applied. 
After carrying out the steps of action planning, the researcher then will describe the implementation of observation. By using the observation sheet, the researcher will record activities conducted by the learners, as well as noting the things inhibiting or supporting the success of students. Results of observation data will be recorded and analyzed and discussed to get answers to the problems that arise.

Implementation steps are as follows: (1) to plan, a lesson which consists of a series of moves consisting of motion of attacks and evasion by the arm. (2) Researchers provide learning materials, which consists of the explanation. This explanation is intended to provide an understanding of the movements to be performed. After giving explanations, the students practice the predetermined motion to be able to perform the movements correctly. The methods are applied to a method of play that lead to the motion of a predetermined stance. The results of all the remarks about the events in the learning process are recorded, as a response to the data and analyzed; the results will be used for consideration in the next step. After getting the core of this problem, what would be done to the students is reflected upon so as to determine what will be done in the next cycles.

Researchers collect all the results obtained in the observation phase. This data is collected and analyzed. From the observations, researchers made a self-reflection by looking at the results, whether or not the results correspond to the lesson plans that have been previously determined. Observations and discussions showed that there is an increase in student motivation and interest in learning Pencak Silat course, thus improving the ability of Pencak Silat and thus achieving the purpose of this study.

\section{Results}

Cycle 1 in this study begins with an explanation of the implementation of the course as it is somewhat different from the previous lecture. Lecture is aimed at improving the quality of teaching and learning activities. Furthermore, the students were given an explanation of the contract and the college learning methods that will be used. After being briefed on the methods that will be presented, students did not show a strong motivation to follow the lectures.

Student in the class were given a brief explanation on what is expected from them. Researchers then started the class with coaching to increase student awareness of the need for serious discipline and meet the agreed rules together, and thus the course will become more fluent.Researchers then conduct coaching on the introduction of Pencak Silat, the definition of Pencak Silat, the history of Pencak Silat, the game rules, perform Pencak Silat moves with the movement of delapan penjuru arah angin stand, doing Pencak Silat stance in pairs, and making sure students understand the models presented in learning Pencak Silat.

The results obtained from the observations made by research assistants during the course were as follows: 1) student still lack understanding about Pencak Silat teaching in physical education, 2) students still do not understand the game approach and understand the model applied in Pencak Silat, 3) students still think that the learning of Pencak Silat is conventional, 4) researchers should continue to give understanding and motivation on game approach oriented learning system.

The purposes of the coaching are to discipline, to motivate, to be creative, and to be able to create movements that can be applied in Pencak Silat. Researchers continue to use appropriate methods and game approach as Pencak Silat teaching model that is expected to improve the ability of students. Students are required to understand some of the concepts of Pencak Silat movements. From the observation, lecturer can do self-reflection based on the results of field notes to assess whether the model is able to increase motivation and knowledge of the students.

At the beginning of the meeting for Cycle 2 of the research, the researcher reminded the importance of cooperation between groups for the achievement of teaching and learning activities. For good teaching and learning process to occur, beside the interaction between lecturer and students, it is also very important for teamwork in developing the models of learning that can achieve specific learning goals. Development activities begin with helping students to understand the game approach conducted by researchers with the stance presented. The work done by the researchers is 1) to help create a method of playing that suits the moves learned, 2) each of the groups formed by the researchers try out with diversity, 3) the students will increase the interest in learning Pencak Silat with the use of the game approach model, 4) students still consider the developed method so that learning will still be interesting.

The observation results obtained during the second training activities were as follows: 1) formation starts running according to plan, 2) students begin to feel the benefits of learning martial arts with game approach, 3) student can begin the creation of play oriented by game approach model.

Pre-planned objectives in the second cycle of coaching are to be realized by preparing better teaching materials. Researchers try to continue helping with the activities, which in turn can execute Pencak Silat movement learning 
with game approach model. Furthermore, students are given tasks in groups to practice at home with moves that are planned to be modified by learning with game approach.

Implementation begins with the act of giving direction to the students that the learning model with game approach is a beneficial method if it is applied in learning Pencak Silat. Material provided is side step and attack movement in Pencak Silat. The students are happy and enthusiastic to continue practicing attack and side step motion. This is a condition that is expected by the researchers so that students can perform Pencak Silat movement well.

Observations obtained from the second cycle are: 1) the implementation of development according to plan, 2) formulation activities with groups of learners increasingly make student passionate to perform movements of Pencak Silat, 3) Pencak Silat atmosphere is more conducive, 4) students have been able to apply Pencak Silat moves with game approach learning model.

Researchers manage to create fun lectures and obtained good movement capabilities. At side step and attack movement, the students can collaborate both with the sequence alternating intermittent movements or continuous, using game approach learning model. In this case, the students have achieved all the targets that are expected from this cycle, thus this cycle has ended and do not need the next cycle. Researchers have created continous good class situation and managed to find the best way for learning and teaching Pencak Silat through game approach model.

Progress of students who took Pencak Silat classes is maximized, researchers have found the answer to the research objectives. Game approach model can improve exercise ability and outcomes, increasing creativity and creating an excited learning environment. Students are able to work individually or in groups to remain creative and create learning model as implementation of game approach model. According to researchers, the cycle stopped here and did not proceed to the next cycle, because the research question has been answered.

After the completion of the second cycle of this coaching, research assistants expressed observations to the researcher. The researchers held discussions to discuss the program of action which will be given later, so that the results achieved can be maintained and can increase better. Discussion results are: 1) guidance on an on-going basis to continue to consult after the lecture was over, 2) require good communication between lecturer and students, 3) game approach model can be applied to Pencak Silat course, 4) teamwork is required between lecturer and students in order to achieve common goals.

\section{Conclusion}

From the description of the data and the discussion that has been discussed in the previous section, it can be concluded from the application of game approach learning model in Pencak Silat course that: (1) The application of game approach learning model can help improve student skills and student learning outcomes. (2) Game approach learning model can build creativity of movements. (3) The application of game approach learning model can build excitement in learning environment. (4) The application of game approach learning model can build togetherness in groups. (5) The application of game approach learning model can build an image that Pencak Silat learning or lecturing can be done with joy and fun atmosphere.

\section{References}

Anthony, D., \& Morris Keith, E. J. (2013). Bermain dan Berolahraga. Bandung: Pakar Raya.

Docket, S., \& Fleer, M. (2000). Play \& Pedagogy in Early Childhood - Bending the Rules. Sidney: Harcourt.

Ibrahim, R. (2001). Landasan Psikologis Pendidikan Jasmani di Sekolah Dasar. Jakarta: Departemen Pendidikan Nasional.

Ismail, A. (2006). Education Games. Yogyakarta: Pilar Media.

Lubis, J. (2004). Pencak Silat Panduan Praktis. Jakarta: Raja Grafindo Persada.

Lutan, R. (2001). Azas-azas Pendidikan Jasmani. Jakarta: Departemen Pendidikan Nasional.

PB IPSI. (1994). Hasil Munas IX Ikatan Pencak Silat Indonesia. Jakarta: PB IPSI.

PB IPSI. (1996). Pedoman Taktik dan Teknik Pertandingan Pencak Silat Olahraga. Jakarta: PB IPSI.

Ronald, D. (2008). Games Motor Learning. United States: Humans Kinetics.

Soemitro. (1991). Permainan Kecil. Jakarta: Depdikbud, Dirjen Pendidikan Tinggi.

Tamat, T. (1986). Pelajaran Dasar Pencak Silat. Jakarta: Miswar.

Wardani, D. (2009). Bermain Sambil Belajar. Edukasia. 


\section{Copyrights}

Copyright for this article is retained by the author(s), with first publication rights granted to the journal.

This is an open-access article distributed under the terms and conditions of the Creative Commons Attribution license (http://creativecommons.org/licenses/by/3.0/). 